\title{
Public participation in British Columbia forest management
}

\author{
by H.W. Harshaw ${ }^{1}$
}

\section{ABSTRACT}

Conceptions and challenges of public participation in British Columbia are reviewed to identify those characteristics of planning processes that serve to benefit or constrain the interests and needs of public stakeholders. Perspectives on public participation, including representative and participatory democracies, and approaches to incorporating public perspectives in decision-making (i.e., shared decision-making, consensus-building, and interest-based negotiation) are presented to demonstrate the different approaches (and their benefits and challenges) available for providing opportunities for public participation. Lessons from other natural resource management contexts are distilled and used to evaluate the $\mathrm{BC}$ context. Three principal forest planning and management frameworks (the Commission on Resources and the Environment, Land and Resource Management Plans, and sustainable forest management certification) are examined in light of whether meaningful opportunities for public participation were provided.

Key words: public participation, British Columbia, Commission on Resources and the Environment, Land and Resource Management Plans, sustainable forest management certification

\section{RÉSUMÉ}

La conception et les enjeux reliés à la participation du public en Colombie-Britannique sont étudiés afin d'identifier les caractéristiques des processus de planification qui agissent positivement ou négativement sur les intérêts et les besoins des intervenants issus du public. Les perspectives sur la participation publique, incluant les processus démocratiques de représentation et de participation, et les approches pour incorporer le point de vue du public lors de la prise de décision (par ex., prise décision partagée, établissement d'un consensus et négociation basée sur l'intérêt) sont illustrées afin de démontrer les différentes approches disponibles (ainsi que leurs avantages et les enjeux) offrant des opportunités de participation publique. Les leçons tirées d’autres contextes de gestion des ressources naturelles sont étudiées et utilisées pour évaluer le contexte propre à la Colombie-Britannique. Trois principaux cadres de planification et d’aménagement des forêts (la Commission sur les ressources et lenvironnement, les Plans de gestion du territoire et des ressources et la certification de l'aménagement forestier durable) sont étudiés à savoir si des opportunités significatives de participation publique sont offertes.

Mots clés : participation publique, Colombie-Britannique, Commission sur les ressources et lenvironnement, Plans de gestion du territoire et des ressources, certification de l’aménagement forestier durable

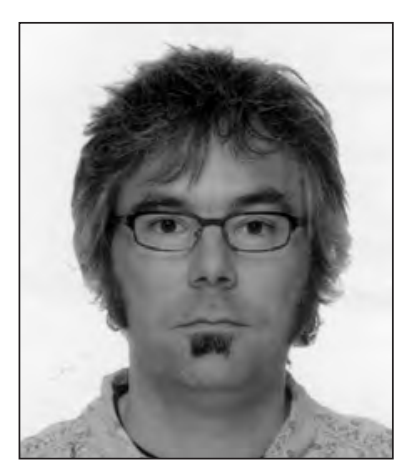

H.W. Harshaw

\section{Introduction}

Land-use decisions involve the distribution of scarce resources; Smith and $\mathrm{McDo}$ nough (2001) note that the issues that frame these decisions "often involve limited resources, but multiple constituencies, creating a situation in which it is impossible for everyone to get what they desire" (p. 241). Land-use planning processes that incorporate, and are responsive to, the full range of social values are vital for the sustainable management of forested landscapes (Canadian Council of Forest Ministers 2003).

The management of publicly-owned forests in British Columbia (BC) has traditionally focused on timber production and economic outputs, and land-use decision-making processes have arguably been dominated by commercial and political interests. However, there has been a shift in forest management priorities toward the management of multiple values and recognition of the important role of non-timber amenities, such as opportunities for outdoor recreation, in the sustainable forest management paradigm (Prins et al. 1990, Kimmins 1991, Carrow 1994, McFarlane and Boxall 2000, Robinson et al. 2001); this shift has been recognized by the forest industry as well (Weyerhaeuser 1998).

The shift in forest management toward the management of multiple values has paralleled the shift in Western public values, which had prioritized material well-being and physical security, but came to emphasize quality of life and amenity values (Inglehart 1977), an increased awareness of environmental values and issues (Dunlap et al. 2000) and of forestry issues, and a shift from forest management priorities being negotiated between governments and the forest industry to forest management practices and specific programs being challenged by environmentalists (Carrow 1999). Carrow has characterized the evolution of public involvement in forestry

\footnotetext{
${ }^{1}$ Forest Resources Management Department, Faculty of Forestry, University of British Columbia, 2424 Main Mall, Vancouver, British Columbia V6T 1Z4. E-mail: howie.harshaw@ubc.ca.
} 


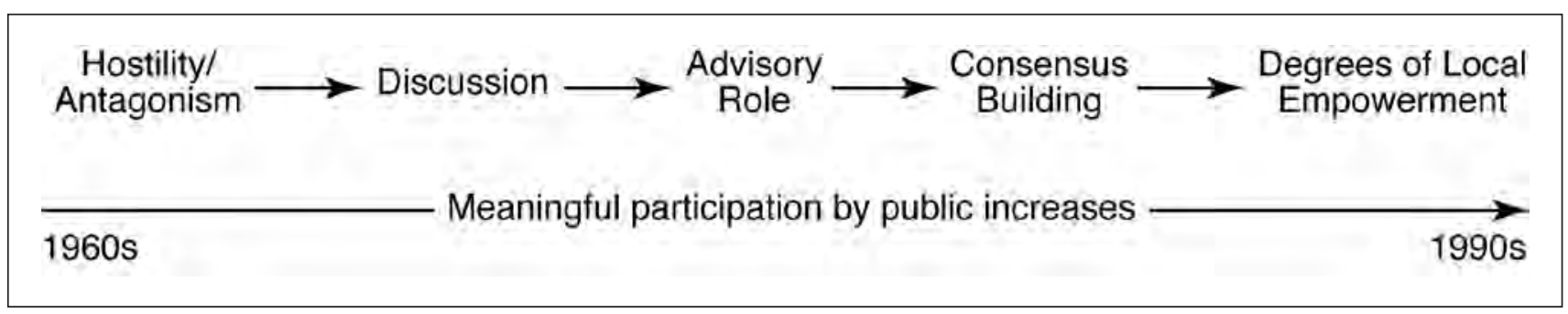

Fig. 1. Progression of public involvement in forestry issues (from Carrow 1999).

issues as one that progressed from an atmosphere of hostility and antagonism in the 1960s to one that reflected greater degrees of local empowerment in the 1990s (Fig. 1). This progression is similar to climbing the rungs of Arnstein's (1969) ladder of citizen participation, as one moves from degrees of non-participation, through degrees of tokenism, to achieve degrees of citizen power.

In addition to increased public awareness and concern for environmental issues, two developments have influenced opportunities for public participation more generally in BC forest management: regional land-use planning and the sustainable forest management certification movement. The role of public participation in regional land-use planning initiatives in BC became formalized, first through the Commission on Resources and the Environment process (CORE) and then through Land and Resource Management Plans (LRMPs). The sustainable forest management certification movement also provides venues for discussions about the distribution and management of forest resources and amenities through public advisory groups. Despite these opportunities for participation, the issues, concerns, and opinions of public stakeholders are not necessarily being heard at forest land-use planning tables. Different land-use planning processes occur in different jurisdictions in $\mathrm{BC}$ such as provincial parks, and municipalities and forest districts, but these are not the focus of this paper. Within the context of the British Columbian experience, I review conceptions and challenges (including social influences and barriers that are relevant to public stakeholders) of public participation to identify those characteristics of planning processes that serve to benefit or constrain the interests and needs of public stakeholders.

\section{Perspectives on Public Participation}

The need for the incorporation of public participation into land-use planning has been recognized since the 1970s (Propst and Bentley 2000). Public participation provides an opportunity for those people that may be affected by a decision to have a voice in that decision. Engaging the public in deliberations about land use can serve to broaden the perspectives considered in decision-making; including the public can also legitimize the decision-making process as transparency in the decision-making process can be more apparent (Wondolleck and Yaffee 2000).

\section{Participatory democracy}

Fundamental to democratic governance is the inclusion of citizens that will be affected by decisions in the decision-making process-it is a matter of fairness (Lauber and Knuth 1999, Hunt and Haider 2001). In the context of decision-mak- ing, fairness can be conceived of as judgments about the legitimacy and relevance of a decision. People's perceptions of fairness influences how they evaluate the procedures that govern the decision-making process (i.e., procedural fairness), such that if the procedures are deemed to be fair, then it is more likely that resultant decisions (i.e., outcomes) will also be deemed to be fair (i.e., distributive fairness) (Lauber and Knuth 1999). The democratic tradition can be conceived of as a continuum from participatory democracy to representative democracy wherein the degree of actual citizen participation and commitment varies (Hemingway 1999).

Participatory democracy requires the direct involvement of citizens in decision-making and assumes that citizens have the both the capacity (i.e., knowledge, skill) and desire to engage in meaningful discussions about the issues at hand. The objectives of participatory democracy include involving a broad cross section of the public, (re)building and maintaining a sense of community, and restoring a sense of selfreliance and self-worth to communities and their members (Overdevest 2000). As Hemingway (1999) has noted, "[p]articipatory democracy is in this sense a communicative process, and the citizen, rather than groups, is assumed to be the basic unit in it" (p. 153). The value of having opportunities for public discussions has been examined by Delli Carpini et al. (2004), who argue that even the act of public deliberation, a formal (e.g., a town hall meeting) or informal (e.g., a discussion among friends) approach to public participation that permits the development and expression of ideas, can lead to desirable outcomes such as increased social capital ${ }^{2}$, as people that engage in public deliberation are more likely to become involved in other forms of civic engagement. In addition to being characterized as being communicative, participatory democracy is a cooperative process.

\section{Representative democracy}

Representative democracy employs citizen proxies to represent and advocate for the interests of their constituencies, or stakeholders, with "the basic acts entailed being the calculation of interest and the manipulative persuasion of others" (Hemingway 1999, p. 152). Overdevest (2000) has suggested that representative democracy arose out of a need for proxy

\footnotetext{
${ }^{2}$ Social capital can be considered social goods, such as information and social influence, which are produced and dissipated through social relations. Scholars define social capital by its function: "It is not a single entity, but a variety of entities having two characteristics in common: They all consist of some aspect of social structure, and they facilitate certain actions of individuals who are within the structure" (Coleman 1990: 302).
} 
representatives as citizens' time can be constrained (e.g., biographical availability ${ }^{3}$ ), and that members of the public generally have limited capacities to understand the complexities of decisions; other possible constraints on people's availability include their geographical distance from the locus of planning and the financial costs associated with participation. For example, in forest land-use planning, people may find it difficult to choose among alternative management scenarios and relate potential outcomes to personal preferences. As demands on citizenship are not great in representative democracies, it has been labelled "weak citizenship", while participatory democracy can be labelled "strong citizenship" (Hemingway 1999). A comparison of typical attributes of representative and participatory democracies is presented in Table 1.

Table 1. Characteristics of participatory and representative conceptions of democracy

\begin{tabular}{lcc}
\hline & \multicolumn{2}{c}{ Form of democracy } \\
\cline { 2 - 3 } Characteristics & Participatory & Representative \\
\hline Citizen involvement & More & Less \\
Focus & Individual & Group \\
Style & Communicative & Adversarial \\
Orientation & Process & Outcome \\
Model & Developmental & Market \\
Demand on leisure time & Greater & Less \\
\hline
\end{tabular}

Adapted from Hemingway (1999, p. 152).

Regardless of which democratic tradition frames a decision-making process, it is important that meaningful opportunities for public involvement be explicitly incorporated into that process. Hunt and Haider (2001) conclude that "[d]espite the different rationales for increased public involvement in decision-making, the resonate echo is that people must be involved in these processes" (p. 874).

\section{Approaches to public participation in natural resource manage- ment}

Public participation in land-use decision-making has been defined as "any of several 'mechanisms' intentionally instituted to involve the lay public or their representatives in administrative decision-making" (Beierle and Cayford 2002, p. 6). Many authors have discussed the importance of incorporating opportunities for meaningful input into land-use planning processes (e.g., Wondolleck and Yaffee 2000, Daniels and Walker 2001, Hunt and Haider 2001, Beierle and

\footnotetext{
${ }^{3}$ In McAdam's (1986) examination of high- and low-risk social activism, he notes that biographical availability, or "the absence of personal constraints that may increase the costs and risks of movement participation, such as full-time employment, marriage, and family responsibilities" (p. 70), plays a role in the recruitment of members to social movements. This concept has also been termed biographical constraints (McAdam 1992). Characteristics that may act as biographical constraints include post-secondary education enrolment, home region, and race.
}

Cayford 2002, Halseth and Booth 2003), and divesting technical details from policy-making: "Rather than seeing policy decisions as fundamentally technical with some need for public input, we should see many more decisions as fundamentally public with the need for some technical input" (Beierle and Cayford 2002, p. 75). Although some authors contend that " $\mathrm{i}] \mathrm{t}$ is now widely accepted that members of the public should be involved in environmental decision-making" (Tuler and Webler 1999, p. 437), there is less consensus about what public involvement entails; for example, what degree of involvement ought to be accorded to individual members of the public?

Public participation constitutes a redistribution of power whereby the general public are accorded opportunities to engage in decision-making through the sharing of information, knowledge, and ideas to effect change. For Arnstein (1969), public participation is an inclusive mechanism in decision-making that empowers citizens that typically do not have power: "it is the means by which they can induce significant social reform which enables them to share in the benefits of the affluent society" (p. 216). An important distinction of public participation in forest land-use decision-making is that the decisions being made are about the allocation of scarce resources amongst a host of differing stakeholders, including commercial (e.g., timber and fibre) and public (e.g., outdoor recreation, aesthetics, access) interests. The key to effective public participation in decision-making is the degree of power (i.e., influence) that members of the public have (Buchy and Hoverman 2000); this has also been noted by Arnstein (1969), wherein "participation without redistribution of power is an empty and frustrating process for the powerless" (p. 216). One typology of the degree of influence associated with public participation is presented in Fig. 2.

In this typology, Arnstein (1969) distinguishes between eight different degrees of participation and influence. The bottom five rungs of this ladder of participation represent mechanisms that do not reflect meaningful opportunities for public participation; these mechanisms allow citizens to offer advice and be heard, or provide opportunities for decisions to

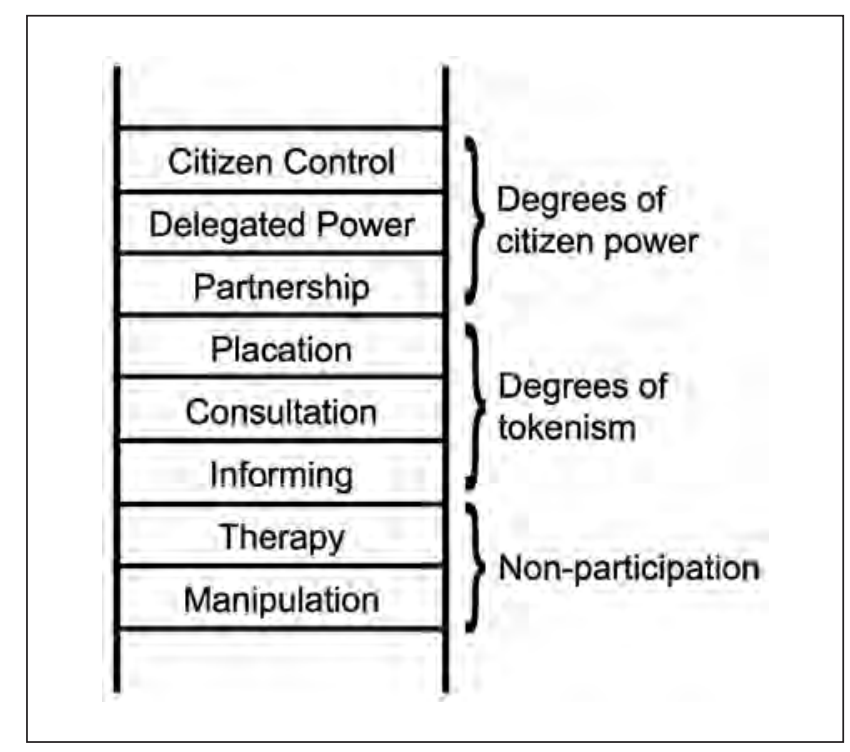

Fig. 2. A ladder of participation (Arnstein 1969) 


\begin{tabular}{|c|c|c|c|c|c|}
\hline & \multirow[b]{2}{*}{ Mechanism } & \multicolumn{4}{|c|}{ Feature } \\
\hline & & Selection of participants & Type of participant & Type of output & Seek consensus? \\
\hline 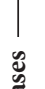 & $\begin{array}{l}\text { Public meetings } \\
\text { and hearings }\end{array}$ & $\begin{array}{l}\text { Usually open access; } \\
\text { group size ranges widely }\end{array}$ & Average citizens & Information sharing & No \\
\hline . & $\begin{array}{l}\text { Advisory committees } \\
\text { not seeking consensus }\end{array}$ & $\begin{array}{l}\text { Small group of participants } \\
\text { selected based on } \\
\text { characteristics }\end{array}$ & $\begin{array}{l}\text { Average citizens, } \\
\text { interest group } \\
\text { representatives }\end{array}$ & $\begin{array}{l}\text { Recommendations } \\
\text { to agency }\end{array}$ & No \\
\hline 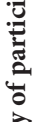 & $\begin{array}{l}\text { Advisory committees } \\
\text { seeking consensus }\end{array}$ & $\begin{array}{l}\text { Small group of participants } \\
\text { selected based on } \\
\text { characteristics }\end{array}$ & $\begin{array}{l}\text { Average citizens, } \\
\text { interest group } \\
\text { representatives }\end{array}$ & $\begin{array}{l}\text { Recommendations } \\
\text { to agency }\end{array}$ & Yes \\
\hline 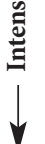 & $\begin{array}{l}\text { Negotiations and } \\
\text { mediations }\end{array}$ & $\begin{array}{l}\text { Small group of participants } \\
\text { selected based on } \\
\text { characteristics or specific } \\
\text { interests }\end{array}$ & $\begin{array}{l}\text { Interest group } \\
\text { representatives }\end{array}$ & Agreements to parties & Yes \\
\hline
\end{tabular}

Source: Beierle and Cayford (2002, p. 45)

be explained and advocated for. These bottom-rung mechanisms that lack decision-making authority are the most frequently used forms of participation opportunities (Propst and Bentley 2000). The top three rungs of the ladder represent opportunities for the public to influence decisions in which they have a stake: these are meaningful opportunities for public participation. The benefits of meaningful public participation do come with responsibilities for participants such as knowledge acquisition about the issue(s) at hand, the ability to communicate one's ideas and opinions, and to effectively negotiate one's interests (Arnstein 1969, Shindler and Neburka 1997, Overdevest 2000). These responsibilities borne by public participants contribute to the legitimacy of a planning process.

In an examination of resource planning in the United States, Daniels and Walker (2001) conclude that public policy is threatened by poorly defined direction and a lack of effectiveness, and may be characterized as lacking social legitimacy. These authors argue that effective policy "[is] an adaptive process; uses the most appropriate science and technology; is implementable; [and] has low transaction costs" (p. 2). To achieve social legitimacy, effective resource planning policy should be rational and solutions technically sound, and include affected publics through collaborative mechanisms.

Opportunities for public participation in decision-making have had an increasing role in land-use policy-making over the past thirty years. In their review of 239 case studies of public participation in American environmental decisionmaking, Beierle and Cayford (2002) describe the transition of environmental decision-making from that of the managerial model, to decision-making processes that recognized pluralism, to an atmosphere that recognized popular democratic theory. The managerial model is a largely utilitarian approach to resource management that relied upon experts to identify planning goals and objectives and make decisions in the public's interest; this approach to planning has also been termed "rational planning" (Payne and Graham 1993).

Managerialism gave way to the concept of pluralism, which acknowledged that the public good was relative to who the affected public was. Under this approach to resource planning, government administrators became the arbiters of the interests of the different constituencies that had stakes in the decisions. In the final stage of this transition, resource decision-making has adopted popular democratic theory, which "stresses the importance of the act of participation, not only in influencing decisions but also in strengthening civic capacity and social capital" (Beierle and Cayford 2002, p. 4). This inclusion and involvement of members of the public with an interest in planning outcomes (i.e., stakeholders) throughout the planning process, including the identification and framing of planning goals and objectives, has been termed "transactive planning" (Payne and Graham 1993). Although the transition to decision-making processes described by Beierle and Cayford (2002) is drawn from the American experience with environmental decision-making, it is strikingly similar to BC's experience with the rise of public participation in land-use planning and social forestry (Kimmins 1991, Weyerhaeuser 1998, Carrow 1999, Robinson et al. 2001, Sheppard and Achiam 2004).

Beierle and Cayford (2002) argue that planning success is a function of the intensity of the mechanisms employed for involving the public in decision-making, and not the context of planning (i.e., issues, institutional setting, pre-existing relationships). In their examination of public participation in environmental decision-making, the authors conclude that more intensive participatory mechanisms are more likely to succeed (Table 2). However, as the intensity of participation increases, the process moves away from the tradition of participatory democracy toward that of representative democracy. Mechanisms, such as open houses often involve large numbers of people, but may be perceived as hostile settings by some members of the public, as open houses can devolve into opportunities for announcing and defending decisions that have already been made, and may not provide meaningful opportunities for participation. Yet, more intensive processes, such as negotiations, engage fewer people, are less likely to be reflective of socioeconomic characteristics, and are more limited in outreach to constituencies and communities (Buchy 
and Hoverman 2000, Overdevest 2000, Beierle and Cayford 2002). Beierle and Cayford (2002) note that more intensive processes "demonstrate a strong tendency to reach consensus by leaving out participants or ignoring issues" (p. 48), and that "as processes intensify, the range and representativeness of voices heard-as well as the social benefits of education, conflict resolution, and trust formation-tend to narrow down to the relatively small group of active participants" (p. 48). These authors also contend that more intensive processes can be more successful at overcoming pre-existing conflict amongst constituencies.

The degree of public participation that a decision-making process will incorporate should be clearly defined at the beginning of the process to avoid confusion and elevated expectations, and to provide a criterion for measuring the success of the process (Shindler and Neburka 1997, Buchy and Hoverman 2000). Further, the participation of public constituencies should not be limited to the decision-making process, but should extend to plan implementation and planning outcome evaluation (Shindler and Neburka 1997, Beierle and Cayford 2002, Delli Carpini et al. 2004).

It is important to recognize that the situations and issues being confronted by decision-making processes that incorporate public participation, as well as the communities that are affected by the decisions, are unique and require specific approaches to the issues at hand. No single set of procedures can be applied universally to public participation processes; local adaptations will be necessary (Shindler and Neburka 1997, Tuler and Webler 1999). A common approach to meaningful public participation in BC forest land use is shared decision-making. Shared decision-making is a type of decision-making that is based on consensus-building, interestbased negotiation, and collaboration. Within this context, consensus-building aims for win-win solutions and seeks to reduce power imbalances; it has been characterized as being "free from the tyranny of the majority" (Williams et al. 1998a, p. 864). Consensus-building is dependent upon the willingness of all parties to pursue consensus and agree to outcomes, agreement that consensus is the most appropriate means of reaching agreement in a given situation, as well as the political will of government to embrace the consensus process and outcomes.

Interest-based negotiation focuses on stakeholder interests rather than positions. In this sense, interests are fundamental goals that are based on the hopes, desires, concerns, and fears, whereas positions are desired end-states. Interest-based negotiation is premised on principled negotiation, and attempts to "separate the people from the problem; focus on interests, not positions; invent options for mutual gain; and insist on using explicit objective criteria" (Williams et al. 1998a, p. 865).

Collaboration "occurs when stakeholders embroiled in conflict agree to explore their differences and seek solutions that go beyond their own limited vision of what is possible" (Williams et al. 1998a, p. 865). By encouraging planning participants to accommodate other stakeholder interests without necessarily compromising their own, shared decision-making outcomes can result in greater public ownership of decisions. However, there are limitations to collaborative planning methods, including ideological and value differences among stakeholders, institutional resistance to change, a lack of trust among participants and between participants and government, and imbalances in power among stakeholders. Time is also an important factor when considering collaborative decision-making processes - due to the limitations already mentioned, the decision-making process can take longer than traditional processes (Day et al. 2003).

It should be noted that the three approaches to meaningful public participation need not be independent and can overlap; thus, for example, it is possible for collaboration to occur with different levels of consensus.

The inclusion of a broad array of stakeholders and ideas in planning processes that have high degrees of public participation permits the incorporation of experience and knowledge that can serve to produce innovative planning outcomes that are more reflective of community interests (Day et al. 2003, Finnigan et al. 2003; Frame et al. 2004). Further, the sharing of knowledge through these collaborative processes can help to increase the knowledge and social capital of participants (Beierle and Cayford 2002, Finnigan et al. 2003).

Benefits of incorporating public participation into natural resource decision-making generally, and forest land-use planning in particular, include: (1) decisions that have been reached through public participation are more publicly acceptable and more likely to be implemented (i.e., social license); (2) public participation improves the relationship between management agencies and the public; and (3) public participation in decision-making can reduce resource management conflicts (Lauber and Knuth 1999, Buchy and Hoverman 2000).

Although there are pragmatic reasons for adopting public participation mechanisms into land-use decision-making, such as increased ownership of outcomes by participants (Wondolleck and Yaffee 2000), Beierle and Cayford (2002) identify five goals of public participation that should also serve to produce more effective planning solutions: "Incorporating public values into decisions, ...Improving the substantive quality of decisions, ... Resolving conflict among competing interests, ...Building trust in institutions, ... [and] Educating and informing the public" (p. 6). Wondolleck et al. (1996) note that a broader representation of interests at planning tables can lead to a broader set of potential solutions being identified.

\section{Challenges of public participation}

In a recent survey of people living in nine timber-dependent communities in $\mathrm{BC}$, two-thirds of respondents agreed that there needed to be more opportunities for them to have input into forest management decisions, yet less than one-half felt that they knew enough about forests and forestry to provide meaningful input into these decisions (Harshaw and Sheppard 2007). This suggests that people do want to be involved in decisions about forestry management; but caution is required in interpreting the input that is received. Forest landuse planning is a complex undertaking. This complexity stems from bringing together multiple constituencies, each with their own deeply held values and world-views, to discuss and resolve multiple issues that are governed by multiple policies requiring a certain degree of scientific and technical knowledge in settings that are often plagued by scientific and technical uncertainty (Daniels and Walker 2001). Wondolleck and Yaffee (2000) have characterized resource management as being predominantly utilitarian and brokered by technocrats, who typically view under-use as wasteful. It must be recognized that current land-use planning processes are an 
improvement over past processes, especially in terms of the degree to which information is made available, and the degree of opportunity that the public has to become involved (Wondolleck et al. 1996). Yet, challenges remain. Overdevest (2000) examined whether the decision-making process employed for public involvement in the Nantahala National Forest in North Carolina was representative of public values and found that representation is more likely to be achieved if structural barriers to participation in the process can be overcome. For example, people with lower incomes or little discretionary time were less able, and less likely, to become involved in land-use planning exercises.

In their examination of how individually held capital can contribute to the production of collectively held social capital through political participation, Tindall and Cormier (2008) note that social networks can provide information that can facilitate political participation and make political engagement easier. However, there are countervailing influences (e.g., family, employer, personal reputation) that make demands on a person's time and resources that may preclude active political engagement; a person's social position (i.e., biographical availability) can play a role in their degree of political action as well. This study found that political participation is affected by political participation values (i.e., wanting to say more at work, or in the community) and sociodemographic characteristics (i.e., age, retirement status); the more social connections a person has (and the more diverse these connections are), the more likely they will become engaged in political activities. Further, the resources produced through a person's political network increases their sense of political efficacy, which increases their political participation (and the more active a person is, the more diverse their network ties are likely to be).

Putnam (1995a) has noted that "[ $t$ ] he norms and networks of civic engagement also powerfully affect the performance of representative government" (p. 66), as successful outcomes in social issues (e.g., education, health, urban poverty) are more likely in "civically engaged communities". This author has argued that the quality of governance is determined by the degree of civic engagement (e.g., voter turnout, newspaper readership, club membership). In an attempt to explain the erosion of social capital in the United States, Putnam (1995b) identified five socio-demographic characteristics that influence civic engagement: education, income, urban or rural residence, gender, and age. Education "is by far the strongest correlate... of civic engagement" (Putnam 1995b, p. 667): the more education a person has, the more likely they are to engage in civic activities; this relationship is likely due to the skills acquisition that one accrues over time spent in school and the potentially resultant higher income levels. This author also found that people with lower incomes are less engaged in community life than those with higher incomes; that men have more social associations than do women, but spend less time at them than women do; and that "age is second only to education as a predictor of all forms of civic engagement and trust" (p. 673), as older people are typically more socially engaged and trusting.

One challenge to public participation is that participatory approaches are often less effective than representative approaches. Effective participation by the public requires knowledge of issues, skills (e.g., negotiation), and resources (e.g., time) that may be limiting factors in the participation of those citizens that would otherwise be inclined to participate (Wondolleck et al. 1996, Overdevest 2000, Wondolleck and Yaffee 2000). Thus meaningful public participation becomes the participation of public representatives-which in itself may not be a bad thing, provided that these representatives are advocating for the needs and interests of their constituencies and are in fact representative of their constituencies. Daniels and Walker (2001) describe the "juxtaposition between technical competence and open process" (p. 4) as a paradox, as achieving one may compromise the ability to achieve the other.

Other challenges to effective public participation include imbalances in power and poorly defined accountability mechanisms of the process which can exclude the public interest (Frame et al. 2004). Compounding these difficulties are uncertainties among participants about the process (both in terms of what the planning goals and objectives are as well as their role as participants) and the intentions of other stakeholders, and different assessments of acceptable outcomes or actions based on constituency needs and values (Daniels and Walker 2001).

Public representatives in planning processes have been referred to as members of civil society, or those people representing constituencies other than those of government or industry: "These stakeholders are not professional natural resource managers, nor do they have any direct pecuniary interest in resource management decisions" (Finnigan et al. 2003, p. 15). Civil society stakeholders typically have fewer resources than government and industry, including skills, funding, time, experience (Buchy and Hoverman 2000, Daniels and Walker 2001); these stakeholder groups also tend to have weaker organizational structures. These deficiencies can lead to what has been termed the "two table problem", wherein civil society stakeholders do not have the time or resources to participate at both the official planning table and their own constituency table, which can result in a compromise of stakeholder accountability to their constituencies. Consequently, two barriers for civil society stakeholders are commitments of time and financial resources that are required for effective participation, and the power imbalances that exist among stakeholders (Finnigan et al. 2003).

Halseth and Booth (2003) employed a household survey to assess the BC public's familiarity with resource planning processes. Among their findings were that fewer than onequarter of respondents had attended a local planning meeting and that the most common form of communication about these planning processes were media reports, especially local newspapers (although newsletters also played an important role). Respondents identified the need to bolster communication methods employed by planning processes in order to keep the public informed. The suggestions made by planning process participants included increasing the flow of information, providing information to planning table participants in understandable ways, and developing mechanisms to communicate with the general public so they can provide useful input. These findings echo studies by Shindler and Neburka (1997) and Buchy and Hoverman (2000). Planning participants also identified the need to understand how to evaluate public input (Halseth and Booth 2003).

Communication and sharing of information about planning processes with the public has been examined by Wondolleck et al. (1996). These authors identified the importance 
of fostering effective two-way communication between stakeholder representatives and their constituents in order to maintain focus on a group's goals and objectives and to formalize the representative's accountability to constituency. However, it should be noted that such accountably, though necessary, increases the time demands of stakeholder representatives, and may require additional skills to be developed. If forest land-use planning processes are to be representative of the range of public stakeholders then the processes ought to be accessible and be able to address socio-economic barriers to participation. In an examination of whether decisionmaking processes are representative of public values, Overdevest (2000) concluded that: "To the extent that participation in decision-making is conditioned by unbalanced incentives, neither the participatory nor representative democracy models can succeed without overcoming structural barriers to participation [e.g., income, time, knowledge]" (p. 694). To conclude, characteristics of meaningful public participation (including the strength of representation) are summarized as illustrated in Table 3.

As socio-economic representativeness is important in land-use planning (Wondolleck and Yaffee 2000), one criterion for evaluating the success of a planning process is the degree of representation present in the process (Mascarenhas and Scarce 2004). Thus, meaningful public participation is a function of those characteristics identified above. However, it would be unreasonable to expect all of these characteristics to be met in a single process. Meaningful public participation can occur when a majority of the characteristics is met. There is also a link between meaningful public participation and the strength of representation, as meaningful public participation in representative democracies is closely related to the effectiveness of the planning participants. Good representation is characterized as having the right people (e.g., representatives of all of the affected recreation stakeholders) at the planning table who are competent and effective in their roles and in touch with their constituencies; they should be able to influence the planning process and outcomes through meaningful participation (as in Table 3).

The effectiveness of planning participants is a key component of achieving meaningful representation. The importance of clear and open communication between the planning participant and their constituency cannot be over-stated; this type of communication permits relevant issues to be identified and possible solutions to be discussed among affected stakeholder groups.

\section{Forest Land-Use Planning in British Columbia}

A common perception of land-use planning is that it provides certainty. For example, Williams et al. (1998a) offer the following definition: "Land-use planning seeks to outline future intentions for the use of land and resources, providing a predictable basis for allocation, development approval, and environmental management" (p. 863). Key to understanding land-use planning in $\mathrm{BC}$ is to appreciate how land use has traditionally been framed, and how recent developments have challenged these traditions. Gunton (1998) has argued that the paradigm governing land-use planning processes in $\mathrm{BC}$ has historically been based on providing raw materials to other nations. A consequence of this has been that land-use policy has centered on providing a stable environment for resource extraction activities that support the export of raw materials, such as timber; and that any use that is contrary to, or competes with, resource extraction is resisted as economic certainty may be threatened.

Williams et al. (1998a) claim that "BC has been the site of some of the most contentious land-use conflicts in Canada's history" (p. 861). During this contentious period, environmental interests gained prominence over the forest industry's framing of forest land use through media and market campaigns that resulted in what has been characterized as the "war in the woods". Evidence of this conflict included protracted court actions, public demonstrations, acts of sabotage to logging equipment, economic boycotts of forest products, public conflicts between conservationists and industrial interests, and legal battles over native land claims and wilderness protection such as Clayoquot Sound, the Stein Valley, and Gwaii Haanas (Wilson 1998). A result of these conflicts was uncertainty (Williams et al. 1998a). Penrose et al. (1998) suggest four reasons that these land-use conflicts had escalated: a lack of coordination between provincial government ministries, an institutional framework that was driven by economic interests, a lack of trust of land-use managers by stakeholders, and a lack of understanding among stakeholders about how land-use decisions were made. Day et al. (2003) add to these reasons by suggesting that a lack of participation opportunities for the public contributed to the public's mistrust of centralized decision-making in BC.

One of the prominent policy initiatives in $\mathrm{BC}$ used to respond to the forest management crisis in the 1990s was the development of land-use policies through consensus-based processes. A result of the increased influence in forest policy that environmentalists gained through these media battles, as

\section{Table 3. Characteristics of meaningful public participation}

- Achievement of procedural fairness.

- Achievement of distributive fairness.

- Open and transparent process.

- Opportunities to influence process.

- Opportunities to influence outcomes.

- Opportunities for knowledge acquisition.

- Ability of participants to communicate ideas.

- Opportunities to negotiate constituency's interests.

- Intensity of process sufficient to address issue at hand.
- Structural barriers are recognized and addressed.

- People at planning table are representative of their constituency.

- People at table have technical competence.

- Accountability is clearly defined.

- Imbalances in power among planning table participants are addressed.

- Communication between planning participants and their constituencies is strong. 
well as the desire of the provincial Government to achieve peace in the woods, was the initiation of processes that incorporated high degrees of stakeholder participation through shared decision-making in land-use and resource planning, such as the CORE and LRMP processes (Cashore et al. 2001, Halseth and Booth 2003, Frame et al. 2004). One outcome of these processes was a doubling of the area of parks and protected areas in the province (Cashore et al. 2001), evidence that the dominant position of the resource sector was being successfully challenged by environmental (and some recreational) constituencies.

Prior to 1992, responsibility for forest land-use planning had been primarily in the hands of the Ministry of Forests. During this period, timber considerations dominated planning outcomes, and there was little opportunity for public input (Edwards-Craig et al. 2003, Mascarenhas and Scarce 2004). Mascarenhas and Scarce (2004) elaborate and note that the planning process was "unstructured, informal, and generated little, if any, relevant documentation about the planning process" (p. 18). The CORE and LRMP processes introduced the concept of planning tables that drew "disparate sets of local stakeholders and agency officials into the analytic and consensus-building processes that led to regional land use recommendations" (Cashore et al. 2001, p. 40). However, the Government imposed five constraints on land-use planning: (1) a $12 \%$ limit on the area that could be designated as protected areas, (2) a $10 \%$ limit on the area of the province that could be designated as biodiversity areas, (3) a 6\% limit on planning recommendations on impacts to annual allowable cut (AAC), and the removal of (4) forest tenures allocation and (5) AAC calculation from discussion. These all restricted possible planning outcomes and limited collaboration among stakeholders who viewed these constraints as controls, and served to limit public participation (Mascarenhas and Scarce 2004).

\section{The Commission on Resources and the Environment and Land and Resource Management Plans}

The CORE process was created in 1992. In their review of collaborative planning in BC, Day et al. (2003) conclude that CORE "empowered the development of an overall provincial strategy, including regional and strategic land use plans, increased public participation, and Aboriginal involvement, improved government coordination, and dispute resolution processes" (p. 23). CORE was focused on the four areas of the province that were experiencing the most contentious landuse and resource issues: Vancouver Island, CaribooChilcotin, West Kootenay-Boundary, and East Kootenay (Owen 1998). Stephen Owen, the CORE Commissioner, identified the need for the development of land-use planning processes that were inclusive, that addressed the range of values present across the province's landscape, and which contributed to the achievement of social, ecological, and economic sustainability (Owen 1998). To achieve these three objectives, the public's participation in the CORE process had to be meaningful, the resultant land-use management plans would have to balance resource uses and emphasize consensus among stakeholders through shared decision-making, and finally the CORE process had to be comprehensive and consistent across the province and include a mechanism for appeals of decisions and other disputes (Owen 1998).
CORE was charged with fulfilling two mandates. First, CORE would initiate a land-use planning mechanism that would achieve social, ecological, and economic sustainability; develop interagency coordination to assist in the attainment of sustainability; and employ increased levels of public participation in the development of these plans. Second, CORE would monitor and evaluate the process, and advise government as an independent voice. To achieve these mandates, CORE had full public inquiry powers, and could compel testimony and hold public hearings. When CORE was cancelled in 1996, partly due to none of the four CORE processes being able to reach consensus on recommendations to government, the second mandate remained unfulfilled (Day et al. 2003, Gunton et al. 2003).

CORE gave $\mathrm{BC}$ citizens their first opportunity to become actively engaged in regional land-use decision-making processes about Crown land. As this process served as BC's initiation to public participation at a large scale, it is not surprising that some difficulties emerged. Glover (2004) has noted that strong core-group identification may lead to the fragmentation of the collective whole; an example of this may have occurred at the Cariboo-Chilcotin CORE process among tourism operators. Although only one tourism seat was planned for the process, the tourism stakeholders felt that the number of seats they had should match the five seats that forestry stakeholders were allocated. The resultant five tourism seats represented the interests of resorts and campgrounds, freshwater fishing, hotels and restaurants, fish and wildlife, and commercial backcountry (Williams et al. 1998, b). Compounding this fragmentation of tourism interests was an inequity in the allocation of resources to stakeholder representatives and the abilities of the representatives themselves. The level of resources that the Ministry of Forests was able to provide to the forestry stakeholders (e.g., maps, inventories) was not matched by Ministry of Small Business, Tourism and Culture in its supporting role to the tourism sector; the tourism representatives were volunteers, while some of the other resource sectors were represented by paid, professional lobbyists and negotiators (Williams et al. 1998b). An ironic conclusion of the tourism representatives was that the $24 \mathrm{sec}-$ tors that were ultimately represented in the process was too many and resulted in an unwieldy process that was difficult to manage and participate in (Williams et al. 1998a).

The CORE process failed to make substantive progress on land-use zoning. Penrose et al. (1998) suggest that community forestry may be a better vehicle to achieve integrated resource management and coordinate stakeholder input, as it is not a time-bounded process, people have a better-defined stake in outcomes, and the geographic scale is more manageable. Land and Resource Management Pans (LRMPs) were initiated to develop strategic land-use plans for those areas of the province that were not covered by CORE, and were initially managed by the Land Use Coordination Office, and the Ministries of Forests and Environment, Lands and Parks (Day et al. 2003). Shared decision-making continued to be the framework that would be used at the planning tables. Whereas CORE made broad recommendations, LRMPs were to develop more detailed plans (Halseth and Booth 2003).

LRMPs drew local stakeholders and government officials together in consensus-building processes that sought to develop and implement regional land use recommendations 
(Mascarenhas and Scarce 2004). LRMPs differed from CORE in other respects: they dealt with smaller areas of land (subregional scale as opposed to the regional scope of CORE); and government officials, largely in the background at CORE tables, played a more central role in LRMPs. Despite an emphasis on shared decision-making, two distinct groups (sectors) emerged in land-use planning processes throughout the province: conservation and development. LRMP tables could allocate land into four categories: protected areas, special management zones, general resource extraction, and enhanced resource extraction (Frame et al. 2004).

The ideals of public participation that both CORE and LRMP processes aspired to did not reflect the realities of the policies that were ultimately implemented. Cashore et al. (2001) characterize these processes as "regionalized experimentation on a leash" (p. 32), as the premier's office maintained a tight rein on these processes. While citizen representatives at CORE and LRMP tables did have some degree of influence over the recommendations made to government, there was no real change in the way that $\mathrm{BC}$ approached landuse planning as political and economic considerations were influential in the final plans that were adopted. Land-use planning decisions were ultimately made by the provincial cabinet (Cashore et al. 2001).

Edwards-Craig et al. (2003) examined the degree to which shared decision-making (SDM) principles, guidelines, and outcomes were realized in BC's LRMPs, from the perspective of tourism respondents who participated in these processes. A survey was conducted of 31 tourism representatives at 17 LRMP processes that had been conducted between 1995 and 2002. One finding of this research was that tourism stakeholders were generally satisfied with how SDM mechanisms help shape the LRMP outcomes. The main motivation for the tourist representatives' involvement was a perception that the LRMP process was the best way to achieve their constituency's goals, and a belief that that tourism's goals and objectives were clearly identified going into process. The tourism representatives generally agreed that the LRMP process was the best way of developing plans and served public interest, and believed that tourism interests were better accommodated in LRMPs than they would have been in other processes. However, "respondents were not convinced of the value of the end results generated" (Edwards-Craig et al. 2003, p. 41) and were unclear on what the end result actually provided in terms of satisfactory outcomes, implementation strategy, and a shared commitment to implementation. The tourism representative respondents "were even less certain that the resulting LRMPs had actually addressed the specific concerns of the tourism industry" (Edwards-Craig et al. 2003, p. 42).

In their examination of the $\mathrm{BC}$ public's perceptions of resource planning processes, Halseth and Booth (2003) conclude that the CORE and LRMP processes experienced many of the challenges that are common with public participation. These challenges included: lack of a clear mandate give to planning participants; a lack of representative consultation with their constituency groups; a lack of coordination in cross-jurisdictional consultations; a lack of respect for process by some planning participants; a failure to implement policies that reflect consensus reached at the planning tables; and political use of stakeholder funding.
An evaluation of land and resource planning in BC (Frame et al. 2004) asked LRMP participants about their perspectives on the planning process and about planning outcomes. Among these findings were that $56 \%$ of respondents were less than positive about the success of outcomes, and 59\% of respondents were less than positive about whether their interests were addressed. The authors conclude that "the fact that almost half of the participants were not satisfied with the outcome even though fourteen of the fifteen LRMPs were agreed to by consensus or consensus minus one shows that consensus should not be interpreted as stakeholder satisfaction" (Frame et al. 2004, p. 70). Further, 47\% of respondents reported that land-use conflict had not been reduced. Despite these reported shortcomings, $69 \%$ of respondents were in agreement that the planning outcome served the public interest, and $59 \%$ of respondents agreed that the process served needs of individual stakeholder groups. Regarding accountability, $69 \%$ of respondents agreed that the LRMP was accountable to stakeholders and $79 \%$ agreed that they had clear direction from constituency groups (Frame et al. 2004).

\section{Sustainable forest management certification}

The sustainable forestry certification movement has emerged to be an influential player in forest land-use planning in BC. The forest industry's adoption of certification frameworks like the Canadian Standards Association (CSA) and the Forest Stewardship Council (FSC) is changing the ways that land-use planning is practised on tree farm licenses. Driven by market forces that have been influenced by the environmental lobby, forest certification has become a significant influence on forestry practices in BC. These standards have been adopted by forestry companies that seek certification that their management and operational practices are both ecologically and socially sustainable so that they can be competitive in the global timber market (Cashore et al. 2001). A mechanism of forestry certification frameworks-public advisory groups that represent public interests in the forest land-use planning on private managed forestry tenures-provides another venue for consultation on the distribution and management of forest resources and amenities.

Public participation has become a critical aspect of sustainable forest management (CCFM 2000, Hunt and Haider 2001, Sheppard and Achiam 2004). The Montreal Process Working Group (1999) noted, "an informed, aware and participatory public is indispensable to promoting the sustainable management of forests" (p. 2). Many sustainable forest management (SFM) certification frameworks provide mechanisms for deliberations about the distribution and management of forest resources and amenities through the public advisory groups that are meant to represent public interests. Despite these opportunities for participation, the issues, concerns, and opinions of the public are not necessarily being heard at forest land-use planning tables. The forest industry's adoption of certification frameworks such as the CSA and the FSC is changing the ways that land-use planning is practised on forest tenures. SFM plans developed under these frameworks recognize the role of non-timber products and amenity values, and go beyond existing regulatory requirements to incorporate public participation into the development of measures of criteria and indicators of sustainable forest management. SFM plans also articulate strategies for monitoring 
management practices to ensure that sustainability requirements are met (CSA 2002, FSC Canada Working Group 2004). It is important to recognize that forest planning occurs at different levels and as a result, different intensities of public participation are appropriate: strategic-level planning creates broad goals and objectives, such as land and resource management plans, and typically involves members of the public; tactical-level planning typically occurs at the operational scale and can require specialized information, which may be provided to (or from) forest certification public advisory groups (Jeakins et al. 2006). Although the number of forest certification public advisory groups has increased dramatically over the past decade, as has the public's legal right to comment on proposed harvesting and road building plans, there are few formal processes in place to seek public input at a community level.

Public participation is a critical component of the CSA framework (CSA 2003, 2010). Members of public advisory groups are involved in the development of indicators, targets, and thresholds. This requirement is largely due to a recognition of the high degree of public ownership of Canadian forests, and the public's right to play a role in the determination of planning outcomes on public land. The CSA has defined effective public participation as considering "the public's wide range of knowledge, different interests, and varying levels of involvement with regard to SFM, as well as its differing cultural and economic ties to the forest" (CSA 2003, p. 12). The CSA framework is oriented towards consensus in the decision-making process and repeatedly refers to examples of this process. Adherents to the CSA framework must demonstrate that their public participation process is designed and functioning to the satisfaction of planning participants.

The importance of public participation has also been captured in the FSC's Boreal and BC standards. In the Boreal Standard (FSC Canada Working Group 2004), local citizens are accorded meaningful opportunities for participation in the development of management strategies, the management plan, and monitoring activities; however, "meaningful" is not defined, which hampers measurement. Although a broad and balanced range of public interests must be openly sought (FSC Canada Working Group 2004), the desired outcome of this process is not stated. The FSC BC Standard is less specific, but does call for ongoing public participation. Within this framework it is considered a major failure if the rights and interests of directly affected people are not identified and incorporated into a management plan (FSC Canada Working Group-British Columbia Regional Initiative 2003). An example of a localized CSA approach is the Canfor SFM framework (Canadian Forest Products Ltd. 2004), which incorporated public participation in two indicators-one addresses inclusive consultation with stakeholders and the other facilitates capacity-building through collaborative planning processes. Both of these indicators are supported by five measures with associated outcomes where appropriate (Robinson 2006).

Conclusion: Implications for Public Participation in BC An important principle for land-use planning participants is the legitimacy of the process - it should be open, democratic, and transparent-independent of the planning outcome achieved. An important component of legitimacy is the concept of representativeness-the representation of values, interests and concerns. When this legitimacy comes into question, land-use planning may be seen as "a cynical and undemocratic process in the guise of openness and participatory government" (Mascarenhas and Scarce 2004, p. 31).

In BC, the LRMP framework addressed the issue of procedural fairness and permitted planning participants to influence the deliberation processes of the planning table. However, the planning table outcomes were not communicated to the public until well after many of the planning tables had wrapped up. While the LRMP meetings were generally open to the public, their transparency was hampered by a lack of communication to communities of interest in favour of regionally defined geographic communities. The LRMP processes ultimately did not provide opportunities for planning participants to influence planning outcomes, as the land-use decisions were ultimately cabinet decisions (Cashore et al. 2001). Knowledge acquisition played a role in LRMPs as planning participants underwent training about interestbased negotiation and were given presentations by local experts to explain the finer details of issues like forest management; this served to increase the technical competency of planning participants. The intensity of the process was generally sufficient to address the planning issues facing the table; however, structural barriers served to constrain some of the planning tables (e.g., two of the 28 planning participants at the Dawson Creek LRMP were women [BC Ministry of Environment, Lands and Parks 1999]). Imbalances in power among planning table participants existed in some provincial planning tables as evidenced by the experiences of the tourism representatives in the Cariboo-Chilcotin CORE process; additionally, some planning participants were government officials, which may have served to muddy the waters regarding whose interests they were representing. The accountability of the planning tables is difficult to discern, as some planning participants undoubtedly felt they were accountable to their constituencies; however, as the provincial cabinet had the ultimate authority to approve the plans, the case could be made that it was the government to whom planning participants were accountable. Thus, a final assessment of public land-use planning processes in $\mathrm{BC}$ must address the fact that the provincial cabinet ultimately had the authority to approve proposed plans, and did alter some of the plans that were produced. As a result, the procedural strengths of the LRMP framework are outweighed by the political oversight imposed on the process. The above assessment largely holds true for certification processes in the province as well, yet these processes are typically more constrained (especially in terms of the intensity of the process, and addressing structural barriers), as they are led by private corporations. However, in these certification processes accountability is generally very clearly defined.

Although SFM certification explicitly requires public participation in forest management decisions, opportunities for input are not being utilized adequately by the public (Harshaw et al. 2009). Communication efforts between foresters and members of the public can always be improved; however, unless there is a sense of urgency around a topic, local residents do not seem to take advantage of the existing public 
processes. To make opportunities for participation in forest land-use decision-making more accessible, forest managers can link tools such as public surveys to certification and strategic land-use planning processes in order to develop an effective feedback loop between the public who are interested but not participating and those that actively participate at public advisory group meetings.

Although there have been advances in the roles that public participation have played in natural resource decisionmaking, there is evidence that some problems remain. Cashore et al. (2001) conclude that that despite the use of a shared decision-making framework, a focus on consensusbuilding, and an increased level of participation from the public, land-use planning outcomes in $\mathrm{BC}$ have been influenced (and dominated) by economic and political considerations, and have ultimately been cabinet decisions. In a review of national studies of Canadian attitudes towards forest values and management, Robinson et al. (2001) conclude that societal values have not been represented in forest policy, perhaps due to inadequate representation of forest stakeholders. Economic and market concerns have influenced the manner in which public participation has been incorporated into commercial forest management-as forestry companies have sought certification that their management and operations are ecologically, socially, and economically sustainable in order to be seen as responsible corporate citizens and maintain market share, they have formalized the role of public participation primarily through the creation of public advisory groups (CSA 2002). Although these groups make comments and recommendations about forest management plans and address some public concerns, they generally have no decision-making authority and tend to be influenced by the company involved (Parkins 2002).

\section{Acknowledgements}

The author appreciates the suggestions made by Stephen Sheppard and Rob Kozak (Faculty of Forestry, UBC), and Don Luymes (Landscape Architecture program, UBC); these suggestions improved the focus of the paper. Funding for this project was provided by the Sustainable Forest Management Network and the social sustainability research team led by Dr. Tom Beckley.

\section{References}

Arnstein, S.R. 1969. A ladder of citizen participation. American Institute of Planners Journal 35(4): 216-224.

Beierle, T.C. and J. Cayford. 2002. Democracy in Practice: Public participation in environmental decisions. Resources for the Future, Washington, DC.

[BC] British Columbia Ministry of Environment, Lands and Parks. 1999. Dawson Creek Land and Resource Management Plan. Victoria, BC

Buchy, M. and S. Hoverman. 2000. Understanding public participation in forest planning: a review. Forest Policy and Economics 1(1): 15-25.

[CCFM] Canadian Council of Forest Ministers. 2000. Criteria and Indicators of Sustainable Forest Management in Canada: National status criteria and indicators 2000. Natural Resources Canada, Canadian Forest Service, Ottawa.

2003. Defining Sustainable Forest Management in Canada: Criteria and indicators 2003. Natural Resources Canada, Canadian Forest Service, Ottawa.
[CSA] Canadian Standards Association. 2002. CAN/CSA-Z80902 Sustainable Forest Management: Requirements and Guidance. A National Standard of Canada (approved May 2003). Canadian Standards Association, Mississauga, ON.

2010. CAN/CSA-Z809-08 Sustainable Forest Management: National Standard of Canada (approved May 2010). Canadian Standards Association, Mississauga, ON.

Canadian Forest Products Ltd. 2004. A framework for sustainable forest management. Canadian Forest Products Ltd., Vancouver, BC. Carrow, R. 1994. Integrated resource management - A case study of unrealized potential. The Forestry Chronicle 70(1):19-21.

Carrow, R. 1999. Canada's model forest program: Challenges for phase II. The Forestry Chronicle 75(1):73-79.

Cashore, B., G. Hoberg, M. Howlett, J. Rayner and J. Wilson. 2001. In Search of Sustainability: British Columbia forest policy in the 1990s. UBC Press, Vancouver, BC.

Coleman, J.S. 1990. Foundations of Social Theory. The Belknap Press of Harvard University, Cambridge, MA.

Daniels, S.E. and G.B. Walker. 2001. Working Through Environmental Conflict: The collaborative learning approach. Praeger, Westport, CT.

Day, J.C., T.I. Gunton and T.M. Frame. 2003. Toward environmental sustainability in British Columbia: The role of collaborative planning. Environments 31(2):21-38.

Delli Carpini, M.X., F.L. Cook and L.R. Jacobs. 2004. Public deliberation, discursive participation, and citizen engagement: A review of the empirical literature. Annual Review of Political Science 7: 315-344.

Dunlap, R.E., K. Van Liere, A. Mertig and R.E. Jones. 2000. Measuring endorsement of the New Ecological Paradigm: A revised NEP scale. Journal of Social Issues 56(3):425-442.

Edwards-Craig, R., P.W. Williams and T. Gunton. 2003. Backcountry tourism perceptions on shared decision making in B.C. land use planning. Environments 31(3):31-50.

Finnigan, D., T. Gunton and P.W. Williams. 2003. Planning in the public interest: An evaluation of civil society participation in collaborative land use planning in British Columbia. Environments 31(3):13-29.

[FSC] Forest Stewardship Council Canada Working Group. 2004. National Boreal Standard. Forest Stewardship Council (FSC) Canada Working Group, Toronto, ON.

[FSC] Forest Stewardship Council Canada Working Group - B.C. Regional Initiative. 2003. Forest Stewardship Council Regional Certification Standards for British Columbia FSC-B.C. Preliminary Standards. Forest Stewardship Council Canada Working Group, Vancouver, BC.

Frame, T.M., T. Gunton and J.C. Day. 2004. The role of collaboration in environmental management: an evaluation of land and resource planning in British Columbia. Journal of Environmental Planning and Management 47(1):59-82.

Glover, T.D. 2004. Social capital in the lived experiences of community gardeners. Leisure Sciences 26(2):143-162.

Gunton, T. 1998. Forestry land use policy in British Columbia: the dynamics of change. Environments 25(2/3): 8-13.

Gunton, T. I., J.C. Day and P.W. Williams. 2003. Evaluating collaborative planning: The British Columbia experience. Environments 31(3):1-11.

Halseth, G. and A. Booth. 2003. "What works well; What needs improvement": Lessons in public consultation from British Columbia's resource planning processes. Local Environment 8(4):437-455. Harshaw, H.W. and S.R.J. Sheppard. 2007. The BC SFM Public Opinion Survey: What do people think about BC forestry? LINK 9(1):1-2.

Harshaw, H.W., S.R.J. Sheppard and P. Jeakins. 2009. Public attitudes toward sustainable forest management: Opinions from forestdependent communities in British Columbia. BC Journal of Ecosystems and Management 10(2): 81-103. 
Hemingway, J.L. 1999. Leisure, social capital, and democratic citizenship. Journal of Leisure Research 31(2): 150-165.

Hunt, L. and W. Haider. 2001. Fair and effective decision making in forest management planning. Society \& Natural Resources 14(10): 873-887.

Inglehart, R. 1977. The Silent Revolution: Changing values and political styles among western publics. Princeton University Press, Princeton, NJ.

Jeakins, P., S.R.J. Sheppard, F.L. Bunnell and R. Wells. 2006. Extension Note 1 - A framework for sustainable forest management. BC Journal of Ecosystems and Management 7(1): 37-50.

Kimmins, J.P. 1991. The future of the forested landscapes of Canada. The Forestry Chronicle 67(1): 14-18.

Lauber, T.B. and B.A. Knuth. 1999. Measuring fairness in citizen participation: A case study of moose management. Society \& Natural Resources 11(1): 19-37.

Mascarenhas, M. and R. Scarce. 2004. "The intention was good": Legitimacy, consensus-based decision making, and the case of forest planning in British Columbia, Canada. Society \& Natural Resources 17(1): 17-38.

McAdam, D. 1986. Recruitment to high-risk activism: The case of Freedom Summer. The American Journal of Sociology 92(1): 64-90. McAdam, D. 1992. Gender as a mediator of the activist experience: The case of Freedom Summer. The American Journal of Sociology 97(5): 1211-1240.

McFarlane, B.L. and P.C. Boxall. 2000. Factors influencing forest values and attitudes of two stakeholder groups: The case of the Foothills Model Forest, Alberta, Canada. Society \& Natural Resources 13(7): 649-661.

Montreal Process Working Group. 1999. The Montreal Process: Criteria and indicators for the conservation and sustainable management of temperate and boreal forests (2nd ed.). Natural Resources Canada, Canadian Forest Service Montreal Process Working Group, Ottawa.

Overdevest, C. 2000. Participatory democracy, representative democracy, and the nature of diffuse and concentrated interests: a case study of public involvement on a national forest district. Society \& Natural Resources 13(7): 685-696.

Owen, S. 1998. Land use planning in the nineties: CORE lessons. Environments 25(2/3): 14-26.

Parkins, J. 2002. Forest management and advisory groups in Alberta: An empirical critique of an emergent public sphere. Canadian Journal of Sociology 27(2): 163-184.

Payne, R.J. and R. Graham. 1993. Visitor planning and management in parks and protected areas. In P. Dearden and R. Rollins (eds.). Parks and Protected Areas in Canada: Planning and Management. pp. 185-210. Oxford University Press, Toronto, ON.

Penrose, R.W., J.C. Day and M. Roseland. 1998. Shared decision making in public land planning: An evaluation of the Cariboo-Chilcotin CORE process. Environments 25(2/3): 27-47.

Propst, D.B., and S.C. Bentley. 2000. Trends in citizen participation in outdoor recreation and resource management: Manager vs. citizen perspectives. Paper presented at the Trends 2000: 5th Outdoor Recreation and Tourism Trends Symposium, East Lansing, MI.
Putnam, R.D. 1995a. Tuning in, tuning out: The strange disappearance of social capital in America. PS: Political Science and Politics 28(4): 664-683.

Putnam, R.D. 1995b. Bowling alone: America's declining social capital. Journal of Democracy 6(1): 65-78.

Prins, R., W. Adamowicz and W. Phillips. 1990. Non-timber values and forest resources: An annotated bibliography. (No. Project Report 90-03). University of Alberta, Faculty of Agriculture and Forestry, Department of Rural Economy, Edmonton, AB.

Robinson, D.W., M. Robson, M. and R. Rollins. 2001. Towards increased citizen influence in Canadian forest management. Environments 29(2): 21-41.

Robinson, N. 2006. Developing criteria and indicators of sustainable forest management in the Arrow Forest District. Arrow Innovative Forest Practices Agreement (IFPA) Series: Extension Note 2 of 8. British Columbia Journal of Ecosystems and Management 7(1): 50-56.

Sheppard, S.R.J. and C.M. Achiam. 2004. Public participation in forest decision making. In J. Burley (ed.). Encyclopedia of Forest Sciences. pp. 1173-1182. Elsevier Science Ltd., Oxford, UK.

Shindler, B. and J. Neburka. 1997. Public participation in forest planning: 8 attributes of success. Journal of Forestry 95(1): 17-19.

Smith, P.D. and M.H. McDonough. 2001. Beyond public participation: Fairness in natural resource decision making. Society \& Natural Resources 14(3): 239-249.

Tindall, D.B. and J.J. Cormier. 2008. Gender, network capital, social capital and political capital: The consequences of personal network diversity for environmentalists in British Columbia. In N. Lin and B.H. Erikson (eds.). Social Capital: An International Research Program. pp. 282-307. Oxford University Press, Oxford, UK.

Tuler, S. and T. Webler. 1999. Voices from the forest: What participants expect of a public participation process. Society \& Natural Resources 12(5): 437-453.

Weyerhaeuser, G.H. 1998. The challenge of adaptive forest management: Aren't people part of the ecosystem too? The Forestry Chronicle 74(6): 865-870.

Williams, P.W., R.W. Penrose and S. Hawkes. 1998a. Shared decision-making in tourism land use planning. Annals of Tourism Research 25(4): 860-889.

Williams, P.W., R.W. Penrose and S. Hawkes. 1998b. Tourism industry perspectives on the Cariboo-Chilcotin CORE process: shared decision making? Environments 25(2/3): 48-63.

Wilson, J. 1998. Talk and log: Wilderness politics in British Columbia, 1965-96. UBC Press, Vancouver, BC.

Wondolleck, J.M., N.J. Manring and J.E. Crowfoot. 1996. Teetering at the top of the ladder: The Experience of Citizen Group Participants in Alternative Dispute Resolution Processes. Sociological Perspectives 39(2): 249-262.

Wondolleck, J.M. and S.L. Yaffee. 2000. Making Collaboration Work: Lessons from innovation in natural resource management. Island Press, Washington, DC. 